and thrills. Having read chapters on myths and folk-lore, " tall " stories, eyewitness accounts, and exciting adventures like the rescue of mambas and cobras during the Operation Noah project at Kariba, one is brought to sober and chilling reality with an account of snake venoms and their effects. There is also a chapter on the career of "Bwana Byoka " or "Snake Man ", C. J. P. Ionides, perhaps the greatest snake-catcher of them all. Fully half is devoted to a very useful list of snakes found in East, Central, and South Africa, giving descriptions, feeding, distribution, etc., which should prove a valuable field-guide to anyone who may encounter the much maligned serpent. One thing seems certain-it will never deliberately attack you. Even so, many readers will probably close this book with the comment that all "snake men" must be mad, which is perhaps the highest compliment they could wish for.

\title{
ALFRED LEUTSCHER.
}

The Reptiles. By Archie Carr. Time Inc., New York. $\$ 4 \cdot 60$.

There is very little to say about this book beyond " unreservedly recommended ". The text is excellently written and profusely illustrated, mostly in colour, and one wonders how it can be done for the equivalent of thirty shillings. It is just the kind of book to give a teen-age zoologist for whom the standard textbooks are too advanced and the popular works too superficial. But Professor Carr writes a gloomy story, despite its excellence. In his closing section, Twilight of the Reptiles, he writes with such fatality that one can only be left with the feeling that "they had a good time while it lasted "without much hope for the future. Is it too much to hope that such conservation measures as are in existence have not come too late ?

J. I. MEnzies.

Wild Lives of Africa. By Juliette Huxley. Collins. 30s.

This is a most enjoyable and well illustrated book, written attractively and with originality. Juliette's natural gift of self-expression is to be envied. A lover of wildlife and a keen observer, she is above all an enthusiastic conservationist, so no opportunity is lost of pleading the cause of the welfare of Africa's wild creatures. Ex Africa semper aliquid novi is a hackneyed phrase which should long ago have become meaningless, but the author shows how wrong one can be.

The theme is a thirteen-weeks' journey of some thousands of miles, from the Cape to the borders of the Sudan, at incredibly high pressure, by land, water, and air when Juliette accompanied her husband-who has written an "Introduction" and a "Postscript"-on his visits to more than three dozen National Parks and Nature Reserves to study conservation on behalf of UNESCO. The mere contemplation of such an arduous programme would make many a younger heart quail. What was accomplished in so short a time is almost miraculous. Who could better the vivid description of the dying baobab : " In times of drought also, the wise but destructive elephants excavate them with tusk and trunk until the trees hang disembowelled and broken-hearted : they die that way, going limp all over like wet stuffing." Those familiar with the baobab and with elephant damage will recognize the touch of a master hand in this graphic portrayal of the soggy, pulp-like mess to which the great pachyderms can reduce these once mighty trees. Juliette laments " a bath of kipper-smelling water" ; she was lucky, for the reviewer (and his wife) have often had to drink this! One senses an imp of mischief prompting the description of "Julian ... his hair at several angles, like a 